\title{
Development of Teaching Materials for Training Adaptation Courses Based on KKNI Curriculum to Improve Student Learning Quality Department of Sports Sciences
}

\author{
$1^{\text {st }}$ Puji Ratno ${ }^{1}, 2^{\text {nd }}$ Zulfan Heri $^{2}, 3^{\text {rd }}$ Zulfahri $^{3}$ \\ \{pujiratno@unimed.ac.id ${ }^{1}$ \} \\ Sport Sciences Department, Universitas Negeri Medan, Indonesia ${ }^{1,3}$, Sport Education Coaching \\ Department, Universitas Negeri Medan, Indonesia ${ }^{2}$
}

\begin{abstract}
Teaching materials are one of the most important learning tools in the learning process. The training adaptation course is a new course in the Department of Sports Science. So it is very difficult to find a book that can be used as a guide for lecturers and students. The study aims to develop teaching materials for training adaptation courses which will eventually produce textbooks for students. The result of this research is the compilation of an training adaptation book framework that has gone through several expert validation processes. The framework for the contents of the book are:Training and energy systems, Training and respiratory systems, Training and cardiovascular systems, Training and muscular systems, and Training and skeletal systems.
\end{abstract}

Keywords: Development, teaching, material, training, adaptation.

\section{Introduction}

State University of Medan as one of the universities in Indonesia, must be one of the universities that excels in producing human resources. This demand is a challenge that must be realized by the management of Medan State University both by the Rector and lecturers who are an important part in the process of producing these superior resources. As a form of responsibility of higher education institutions in order to provide appropriate quality education and alumni have competence in accordance with their respective fields.

In developing the curriculum in higher education, the Government through Presidential Regulation has issued Presidential Decree no. 08 of 2012 about. The Indonesian National Qualifications Framework (KKNI) and its attachments are used as a reference in the preparation of learning outcomes for graduates from every level of education nationally, to ensure the quality of university graduates throughout Indonesia.Therefore, through the Ministry of Education and Culture, the Minister of Education and Culture has issued a ministerial regulation that regulates technical instructions related to the implementation of the Presidential Regulation through Ministerial Regulation Permendikbud no. 73 of 2013. The issuance of Presidential Decree No. 08 of 2012 and PT Law no. 12 of 2012 Article 29 paragraphs (1), (2), and (3) have had an impact on the curriculum and its management in each program. 
The curriculum which initially referred to the achievement of competencies became referring to learning outcomes. In summary, the KKNI consists of nine levels of academic qualifications for Indonesian HR. With the existence of KKNI, it is hoped that it will change the way of looking at a person's competence, no longer just a diploma but by looking at the nationally agreed qualification framework as the basis for recognizing the results of a person's education broadly (formal, non-formal, or informal) which is accountable and transparent.

The implementation of the KKNI goes through 8 stages, namely through determining the Graduation Profile, Formulating Learning Outcomes, Formulating Study Material Competencies, Mapping Study Materials, Packaging Courses, Formulating Curriculum Framework, Compilation of Lecture Plans. Competence is the accumulation of a person's ability to carry out a measurable job description through a structured assessment, including aspects of individual independence and responsibility in the field of work. Learning outcomes are the internalization and accumulation of knowledge, skills, attitudes, and competencies that are achieved through a structured educational process covering a particular field of knowledge/expertise or through work experience.

In the KKNI curriculum, teaching materials are an important part of the attention in the implementation of the KKNI. Because teaching materials are part of several learning resources in the form of teaching learning materials that are packaged as materials to be presented in the learning process. Teaching materials are learning resources or physical vehicles that contain instructional materials that can stimulate students to learn. Teaching materials in the learning process are an important element in the learning process, this is because teaching materials are materials that will be delivered. Good teaching materials must be adapted to the goals and competencies expected for students. Teaching materials will determine whether or not the expected learning competency objectives are achieved. Thus, teaching materials are the core of the curriculum that serves as a means of achieving goals in the learning process.

Lecturers are the spearhead of education on campus which is one of the important instruments in providing competence for students. Lecturers are people who manage learning activities for students. Everything related to learning activities in the classroom becomes the authority and responsibility of the lecturer. Learning resources, methods and teaching materials are all in the hands of lecturers who are facilitators for students. The implementation of the KKNI curriculum at Medan State University has caused many changes to the curriculum in each study program at Medan State University. This curriculum change also occurred in the Medan State University Sports Science study program. This curriculum change is a form of adaptation to changes in competencies that must be possessed by graduates of the Sports Science study program that are tailored to the needs of stakeholders. Changes occur in existing courses, so there are missing courses that are no longer needed for the current period, and there are courses that appear out of necessity.

The Exercise Adaptation course is a new course in the Sports Science study program. In general, this course is a course that aims to provide knowledge and understanding of body adaptation during exercise. This course is very important for students to know and understand, because with this course students will know how the body adapts to the exercises they do, what changes occur in the human body when they exercise. 


\section{Theory}

Teaching materials are part of several learning resources in the form of teaching learning materials that are packaged as materials to be presented in the learning process. Teaching materials are learning resources or physical vehicles that contain instructional materials that can stimulate students to learn. Teaching materials in the learning process are an important element in the learning process, this is because teaching materials are materials to be delivered. Good teaching materials must be adapted to the goals and competencies expected for students. Teaching materials will determine whether or not the expected learning competency objectives are achieved. Thus, teaching materials are the core of the curriculum that serves as a means of achieving goals in the learning process.

The teaching materials in the presentation are in the form of descriptions that contain facts and principles, norms that are related to rules, values and attitudes, and a set of actions/motor skills. Thus, learning materials basically contain knowledge, values, attitudes, actions and skills that contain messages, information, and illustrations in the form of facts, concepts, principles, and processes related to certain subjects that are directed to achieve learning objectives.

Teaching materials are basically all materials (both information, tools, and texts) that are systematically arranged, which displays a complete figure of competencies that will be mastered by students and used in the learning process with the aim of planning and studying the implementation of learning [1].

Adaptation exercise consists of two words, namely, Adaptation and exercise where according to the Big Indonesian Dictionary adaptation is "how living things cope with the pressures of the surrounding environment to survive. Living things that are able to adapt to their environment are able to: obtain water, air and nutrients (food). overcome physical environmental conditions such as temperature, light and heat. defend life from natural enemies. reproduce. respond to changes in their surroundings.

Living things that are able to adapt will survive, while those that are not able to adapt will face extinction or species scarcity. Humans as living beings also experience physiological adaptations, namely adaptations that include the functions of the body's organs. This adaptation can be an enzyme produced by an organism. There are physiological adaptations that are reversible or can return to the initial condition. For example, if someone who used to live in a coastal area moved to a high mountain area. Then there will be physiological changes, namely an increase in the number of grains of red blood cells (erythrocytes). However, if the person returns to the plain, then slowly the number of erythrocytes will decrease or return to normal as before.

"Training is an activity that takes place continuously, which is carried out systematically over and over again and the burden is increasing day by day" in this case the training here is more of training in sports activities [2].Training is a process for developing complex sports performances by using training content, training methods, organizational actions that are in accordance with goals [3]. Exercise is a systematic sporting activity over a long period of time, progressively and individually improved, which leads to the characteristics of human psychological and physiological functions to achieve the specified goals [4].

Based on the two meanings of the two words above, exercise adaptation is "changes in physiological changes that occur in the human body during exercise". Where the human body is an extraordinary machine in which perfectly coordinated bodily activities occur simultaneously. These bodily events enable complex bodily functions such as hearing, seeing, breathing and processing information without conscious effort. 
When a person performs activities such as walking, he will shift the body system from a resting state to an active state. If the activity is done several times, the body will adapt to the activity. This activity is called "physical activity". This physical activity is a complex process in which the trainer needs to monitor changes in the subject every minute of the activity. Therefore, if someone wants to be an athlete, he or she needs to have a higher level of physical activity than other people.Significant physiological changes can occur in our bodies when physical activity or exercise is carried out continuously. Therefore, the response to exercise has two aspects analogous to the body's response to a stressful environment. One of them is a short-term response that is a single attack after an occasional exercise or can be called acute exercise. The second aspect is the long-term response after regular exercise which facilitates subsequent training and improves performance. This adaptation to chronic exercise is called "training". Adaptation to acute exercise is a response to exercise in which the effect on training.

This short-term as well as long-term response meets energy needs. The rapid increase in energy requirements during exercise requires a balanced adjustment of the blood circulation to meet the increased demand for oxygen, nutrients and the elimination of metabolic end products such as carbon dioxide and lactic acid and the release of excess heat. Shifts in body metabolism occur through coordinated activities of all body systems, namely neuromuscular, respiratory, cardiovascular, metabolic, and hormonal.

The quality of an education and training program is influenced by many factors, including the quality of teaching materials, infrastructure, environment and so on. Teaching materials as one of the tools in learning activities in their fulfillment must be in accordance with the desired competence, without an understanding of this, anyone who will develop teaching materials will have difficulty.Systematic development of teaching materials starting from the design and development process can be in the form of developing their own activities, or using existing teaching materials, to testing teaching materials. Knowledge of the factors that affect the quality of the results need to be considered in the development of teaching materials and procedures for developing systematic teaching materials are also needed. The development of teaching materials needs to be done systematically based on interrelated steps to produce useful teaching materials. Trainers often ignore this systematic procedure for developing teaching materials because they assume that if they are made properly according to the material to be taught, then teaching materials can be used effectively in the learning process. Even though there are several steps that the instructor must take before arriving at the conclusion that the teaching materials have been developed well, and the teaching materials used are indeed good. There are at least five main steps in the procedure for developing good teaching materials, as follows: Analysis, Design, Development, Evaluation, Revision.

\section{Method}

This study uses a Research and Development approach or development research. This research begins with an analysis of the needs of the user as a material to re-design the curriculum. Followed by collecting materials to compile teaching materials. This research was conducted to produce teaching material products in the form of print outs of adaptation training books. The activities carried out include redesigning the curriculum through needs analysis by collecting data from stakeholders, personal trainers, sports coaching science lecturers, sports physiology lecturers related to the curriculum (silabus and SAP) used so far. 
Data were also collected from stakeholders, personal trainers, coaching science lecturers and exercise physiology caregivers. The preparation of teaching materials still pays attention to the sequence and depth of the material discussed. The teaching materials that have been prepared are then held in seminars to produce teaching materials in the form of print outs of good practice adaptation books that are in accordance with the demands of competence.

\section{Results and Discussion}

The result of this research is the compilation of an exercise adaptation book framework that has gone through several expert validation processes, to meet the requirements in development research. The framework of the contents of the book, namely. Exercise and the energy system, exercise and the respiratory system, exercise and the heart and blood vessel system, exercise and the muscular system, and exercise and the skeletal system, Exercise and reflex movements. These results were obtained from 1 focus group discussion (FGD) and two expert validations. The first stage in the form of drafting by researchers, has identified many teaching materials that students must master in order to understand the contents of the Training Adaptation course with the current KKNI curriculum with various assignments in the form of routine assignments, reviewing books, journals and making mini research.

Broadly speaking, the aim of this course is for students to be able to master and understand the changes that occur in the human body when humans practice physical exercise. This course takes place in class theory with lecture and discussion methods, observing changes that occur in the body when humans practice sports. The initial drafts were, exercise training and energy requirements, exercise training and oxygen demand, exercise training and the cardiovascular system, exercise training and changes in muscle mass, exercise training and skeletal work system, exercise training and reflexes, exercise training and needs. body fluids, exercise training and the body's metabolic system, exercise training and the recovery phase.

Focus group discussions were conducted to get input and experts, especially coaching experts and sports physiology to get input, related to the draft of teaching materials that will be developed in the preparation of textbooks for training adaptation courses. There were 5 experts involved in the FGD on the development of teaching materials for this training adaptation course. Three sports coaching experts and two exercise physiologists. From the FGD, there were several inputs to further refine the draft of the teaching material. Of the 9 materials proposed in the initial draft during the FGD, it was reduced to 7 materials after the FGD was conducted, namely, exercise training and energy requirements, exercise training and oxygen demand, exercise training and the cardiovascular system, exercise training and changes in muscle mass, exercise and exercise. skeletal work system, exercise training and reflexes, exercise training and the body's metabolic system. There were two materials that were omitted in the draft of the FGD results, namely, exercise training and body fluid requirements, exercise training and the recovery phase.

After the FGD was conducted, then an expert validation test was carried out to determine whether the draft of the training material adaptation course material was feasible to be used as material in the training adaptation course teaching material in accordance with the IQF curriculum. This validation test involved one sports coaching expert and one exercise physiologist. Agree on draft materials for teaching materials for training adaptation courses with the framework of the book content, namely. Exercise and the energy system, exercise and 
the respiratory system, exercise and the heart and blood vessel system, exercise and the muscular system, and exercise and the skeletal system, Exercise and reflex movements.

\section{Conclusion}

After getting the results of the research and also discussing it in the previous chapter, the conclusion of this research is the compilation of an exercise adaptation book framework that has gone through several expert validation processes, to meet the requirements in development research. The framework of the contents of the book, namely. Training and the energy system, Training and the respiratory system, Training and the cardiovaskular system, Training and the muscular system, and Training and the skeletal system, Training and reflex movements.

\section{References}

[1] Arikunto S. Prosedur Penelitian: Suatu Pendekatan Praktek. Jakarta: Rineka Cipta; 2002.

[2] Majid A. Perencanaan Pembelajaran Mengembangkan Standar Kompetensi Guru. Bandung: PT Remaja Rosdakarya; 2012.

[3] Bompa T. Theory and Methodology of Training. Toronto: Kendal Hunt Publishing Company; 1994.

[4] Schoenfeld BJ. The mechanisms of muscle hypertrophy and their application to resistance training. J Strength and Conditioning Res. 2010; 24(10):2857-2872.

[5] Harsono. Coaching dan Aspek-Aspek Psikologis dalam coaching. Jakarta: CV. Tambak Kusumah; 1988.

[6] Fitri. Kurikulum Nasional Berbasis Kompetensi Mengacu pada KKNI. Available from: http://lldikti12.ristekdikti.go.id/2013/04/28/kurikulum-nasional-berbasis-kompetensi-mengacupada-kkni.html [Accessed $15^{\text {th }}$ Juny 2021].

[7] Leick L, Plomgaard P, Gronlokke L, Al-Abaiji F, Wojtaszewski JF, Pilegaard H. Endurance exercise induces mRNA expression of oxidative enzymes in human skeletal muscle late in recovery. Scand J Med Sci Sports. 2010; 20(4):593-599.

[8] Sagala S. Kemampuan Profesional Guru dan Tenaga Kependidikan. 2 ${ }^{\text {nd }}$ Edition. Bandung: Alfabeta; 2009.

[9] Vega RB, Konhilas JP, Kelly DP, Leinwand LA. Molecular Mechanisms Underlying Cardiac Adaptation to Exercise. Cell Metab. 2017; 25(5):1012-1026.

[10] Wilk M, Zajac A, Tufano JJ. The Influence of Movement Tempo During Resistance Training on Muscular Strength and Hypertrophy Responses: A Review. Sports Medicine. 2021; 51(8):16291650.

[11] Yamane M, Teruya H, Nakano M, Ogai R, Ohnishi N, Kosaka M. Post-exercise leg and forearm flexor muscle cooling in humans attenuates endurance and resistance training effects on muscle performance and on circulatory adaptation. Eur J Appl Physiol. 2006: 96(5);572-580.

[12] Diran Z. Teknik Pesnyusanan Bahan Ajar. Available from: https://zulkarnaini.my.id/2009/06/28/131/ [Accessed 20 $0^{\text {th }}$ Juny 2021]. 